\title{
Constitutional Basis of Ensuring the Right to Privacy in the Age of Informatization
}

\author{
Madiev Fakhriddin Khoshim ugli, \\ Lecturer of Constitutional Law Department \\ of Tashkent State University of Law \\ E-mail: fmadiyev92@gmail.com
}

\begin{abstract}
The following article analyzes the theoretical and practical essence and importance of privacy. As well as that the author points out main issues in this sphere. Besides that, laws on privacy in the experience of Uzbekistan is discussed.
\end{abstract} data.

Keywords: privacy, constitutional rights to privacy, information technology, secrecy, personal

\section{Introduction}

What is privacy? We all have some intuitive sense that there are certain aspects of life that are "private" and view these aspects of life as related to each other. But what does it mean when we say that these aspects of life are "private"?

According to Solove D. this question is very important for making legal and policy decisions. Many recognize the importance of privacy for freedom, democracy, social welfare, individual wellbeing, and other ends. Many also assert it is worth protecting at significant cost.[1]

As well as that the individual shall have full protection in person and in property is a principle as old as the common law; but it has been found necessary from time to time to define anew the exact nature and extent of such protection. Political, social, and economic changes entail the recognition of new rights, and the common law, in its eternal youth, grows to meet the demands of society.[2]

Coursing through this web is facts, which makes beneficial our phones, radios, televisions, pagers, faxes, satellite dishes, and pc networks. The revolution in our communications infrastructure particularly, the explosive growth of the internet - has basically transformed how we create, acquire, disseminate, and use records.[3]

\section{Main part}

Privacy is a value so complex, so entangled in competing and contradictory dimensions, so engorged with various and distinct meanings, that I sometimes despair whether it can be usefully addressed at all.[4]

Resolving the status of privacy is easier than resolving questions concerning the characteristics of privacy. Is privacy related to secrecy, freedom of action, sense of self, anonymity, or any specific combination of these elements? The answers here are not -constrained by methodological concerns. The crucial test is the utility of the proposed concept in capturing the tenor of most privacy claims, and in presenting coherent reasons for legal protection that will justify grouping these claims together. Gavison's conception of privacy as related to secrecy, anonymity, and solitude is defended in these terms.[5]

Solove D. isolates and reviews three different and in some respects incompatible concepts of privacy that are each mentioned in the Prologue to The Unwanted Gaze. The first connects privacy to the creation of knowledge; the second connects privacy to dignity; and the third connects privacy to freedom. I shall argue that the first concept should not be understood as a question of privacy; that the second is a helpful way of apprehending privacy, but that it should focus our attention primarily upon forms of social structure; and that the third is best conceived as an argument for liberal limitations on government regulation.

Rosen introduces the first sense of privacy early in the Prologue when he seeks to explain the 
"sense of violation". [6]

In the current process of informatization, with the development of the internet and other communication networks, the amount of information scale is sharply increased, and since its forms are becoming more diverse, there are situations that humiliate the honor and dignity of a person, lead to the spread of information about his personal life. It is also important to protect the individual from interference in personal life.

Statements about privacy can be either descriptive or normative, depending on whether they are used to describe the way people define situations and conditions of privacy and the way they value them, or are used to indicate that there ought to be constraints on the use of information or information processing. These conditions or constraints typically involve personal information regarding individuals, or ways of information processing that may affect individuals. Informational privacy in a normative sense refers typically to a non-absolute moral right of persons to have direct or indirect control over access to (1) information about oneself, (2) situations in which others could acquire information about oneself, and (3) technology that can be used to generate, process or disseminate information about oneself.[7]

Dissemination of erroneous information in the media that insults the honor and dignity of an individual or business reputation also requires protection from interference in private life. Accordingly, the rights and freedoms of citizens are protected by law.

Acknowledging that there are moral reasons for protecting personal data, data protection laws are in force in almost all countries.[8] The basic moral principle underlying these laws is the requirement of informed consent for processing by the data subject, providing the subject (at least in principle) with control over potential negative effects as discussed above.

In order to legally protect the rights and freedoms of citizens in Uzbekistan, Article 27 of the Constitution guarantees the "right to protection from intrusion into private life", including the right to protection from encroachment on privacy and privacy and the inviolability of the home. No one may enter, search or inspect someone's home, disclose the secrets of correspondence and telephone conversations, except as provided by law."

Only when human dignity is valued can he build his life with dignity. Therefore, a person's honor and dignity are protected. Everyone organizes their life as they wish. Any action that harms the honor and dignity of the people is prohibited.

Article 13 of the Law of the Republic of Uzbekistan "On Principles and Guarantees of Freedom of Information" of 12 December 2002 provides that "Collection, storage, processing, distribution and use are not allowed ", Article 6 of the Law of the Republic of Uzbekistan“" On Mass Media "of January $15,2007^{\prime \prime}$ Insulting the honor and dignity of citizens or business reputation through mass media, privacy In addition, Article 28 of the Law of the Republic of Uzbekistan "On Personal Data" of July 2, 2019 states that "Disclosure and dissemination of personal data is not allowed without the consent of the entity or in the absence of other legal grounds. The requirement to be complied with by the owner and (or) the operator or another person authorized to use the personal data is the confidentiality of the personal data. The owner and (or) operator and other persons authorized to use personal data must not disclose or disseminate personal data to third parties without the consent of the subject.

Private life consists of those aspects of a person's personal life that he, by virtue of his freedom, does not want to make the property of others. This is a kind of sovereignty of the individual, meaning the inviolability of his "habitat". It is summarized that the secret in this case does not cover up any antisocial or illegal activities.

It reflects the natural desire of each person to have their own world of intimate and business interests, hidden from other people's eyes. However, civil society understands that the abuse of privacy can be antisocial and illegal. In this case, the society assumes that interference in private life in order to identify illegal actions of a person should only occur on the basis of the law if there are strong, again recognized by law, grounds for suspicion or accusation of this person in the commission of a crime, i.e. 
when a criminal case is initiated. Outside of this, private life is inviolable.

The right of a person to personal and family secrecy, to protect his honor and good name are established. No one can be required to provide information concerning a person's private life. First of all, Private life is the individual freedom of a person. The sphere of private life includes: family relations, the secret of deposits, information about the state of health, intimate life and other aspects of a person's life. If the honor and good name of a person are violated, he has the right to demand through the court punishment and compensation for moral damage;

Everyone has the right to the secrecy of correspondence, telephone conversations, postal, electronic and other communications, in connection with which the per lustration (opening) of letters and other postal items, eavesdropping on telephone conversations are prohibited. Article 46 of the Code of Administrative Responsibility of Uzbekistan qualifies these actions as harming a citizen, his rights, freedoms and legitimate interests. Searches, seizure, seizure of correspondence, as well as wiretapping of telephone conversations may be carried out only on the grounds and in accordance with the procedure established by the Code of Criminal Procedure;

The collection, storage, use and dissemination of information about a person's private life without their consent is not allowed. It may seem that this rule restricts the established

Article 29 of the Constitution of the Republic of Uzbekistan gives everyone the right to freely search for and disseminate information, but there is no contradiction between these norms. The main sign of illegality here is the lack of consent of the person to the dissemination of information about him.

If a person's honor and dignity are damaged as a result of any action, appropriate measures will be taken against him.

Often, human dignity is damaged as a result of slander. Not being able to see, envy, etc., also infringes on human dignity.

Society is a community, the common interest of its members, the need to follow the rules of living in it, while everyone can organize their lives within the law. So, Law is perceived in a variety of ways.[9] provision of information are needed to establish the norm for the product of norm-making activities to be effective in regulating social relations. Therefore, law makers should consider the private life of any person.[10]

Unfortunately, as a result of non-compliance with the procedures established by the Constitution and legislation, citizens are now disseminating information, messages and conclusions based on their private lives in the media and social networks.

With the development of mass communications, today we are witnessing the dissemination and dissemination of personal and family secrets of a person on social networks and Internet sites, unfortunately, without his consent. There has also been an increase in the use and dissemination of personal information (photos, names, positions, etc.) on social networks, websites and bloggers' websites without his consent. As a result, many social network users suffer from violations of their privacy and the dissemination of personal information.

It is a fundamental right of an individual to be protected from any interference or aggression in his or her private life. After all, the Constitution of Uzbekistan recognizes this value and guarantees the right to protection from interference in private life.

\section{References:}

1. Solove D. J. Conceptualizing Privacy. - 2002.

2. Warren S. D., Brandeis L. D. Right to privacy //Harv. L. Rev. - 1890. - T. 4. - C. 193.

3. Kang J. Information Privacy in Cyberspace Transactions //STANFORD LAW REVIEW. 1998. - T. 50. - C. 1193.

4. Post R. C. Three Concepts of Privacy. - 2001. 
5. Gavison R. Privacy and the Limits of Law //The Yale law journal. - 1980. - T. 89. - №. 3. - C. 421-471.

6. Rosen J. The Unwanted Gaze: The Destruction of Privacy in America. - 2000.

7. Van den Hoven J. et al. Privacy and information technology. - 2014.

8. Косимов, Б., 2020. ВЕРХОВЕНСТВО ПРАВА И ПАНДЕМИЯ КОРОНАВИРУСА СОVID19. Review of law sciences, (2).

9. Sodikov, A., 2019. THE IMPORTANCE OF INFORMATION SUPPLY IN THE PROCESS OF NORM-MAKING. Научныле разработки: евразийский регион, p.55.

10. Bekov, I., 2020. Constitutional and legal basics for the participation of political parties in the formation of the Legislative Chamber of the Oliy Majlis. Journal of Critical Reviews, 7(11), pp.1571-1577.

11. Narimanov, B., ISSUES OF IMPROVEMENT OF LEGAL BASIS OF LIQUIDATION OF NON-GOVERNMENTAL ORGANIZATIONS IN UZBEKISTAN.

12. Tursunbaevich, M.B., 2019. Collision principles in labor relations complicated by a foreign element: Experience of Uzbekistan. International Journal of Recent Technology and Engineering, 8(2), pp.4094-4098.

13. Ботиров, Х., 2020. ПРОБЛЕМЫ КОНСТИТУЦИОНАЛИЗМА В УЗБЕКИСТАНЕ. Review of law sciences, 3(Спецвыпуск). 